\title{
Changes over 20 years in macronutrient intake and body mass index in 11- to 12-year-old adolescents living in Northumberland
}

\author{
E. S. Fletcher ${ }^{1}$, A. J. Rugg-Gunn ${ }^{1}$, J. N. S. Matthews ${ }^{2}$, A. Hackett ${ }^{3}$, P. J. Moynihan ${ }^{1}$, J. C. Mathers ${ }^{1}$ and \\ A. J. Adamson ${ }^{1 *}$ \\ ${ }^{1}$ Human Nutrition Research Centre, University of Newcastle upon Tyne, Newcastle upon Tyne NE1 4LP, UK \\ ${ }^{2}$ Department of Statistics, University of Newcastle upon Tyne, Newcastle upon Tyne NE1 4LP, UK \\ ${ }^{3}$ Liverpool John Moores University, School of Education, Community and Social Science, IM Marsh Campus, Barkhill Road, \\ Liverpool $L 17$ 6BD, UK
}

(Received 25 April 2003 - Revised 13 April 2004 - Accepted 19 April 2004)

\begin{abstract}
Monitoring adolescent diets over time enables the assessment of the effectiveness of public health messages which are particularly important in vulnerable groups such as adolescents. In 2000, 424 children aged 11-12 years old completed two $3 \mathrm{~d}$ estimated dietary records. On the fourth day one nutritionist interviewed each child to clarify the information in the diary and foods were quantified with the aid of food models. Nutrient intake was calculated using computerised food tables. These children attended the same seven schools in the same Northumberland area as the 11- to 12-year-old children who recorded their diet using the same method in 1980 ( $n$ 405) and 1990 ( $n$ 379), respectively. Height and weight, and parental occupation were recorded in all three surveys for each child. Height and weight were used to calculate BMI, weight was used to estimate BMR and parental occupation was used to determine social class. Comparing the macronutrient intakes in 2000 with 1980 and 1990, energy intakes (EI) fell in boys (to 8.45 MJ) and girls (to 7.60 MJ). This fall may, at least in part, be due to an increase in low energy reporting. For 1980, 1990 and 2000 the percentage of boys with EI:BMR below 1.1 was 6,15 and $23 \%$, respectively; for girls, 3,14 and $18 \%$, respectively. Percentage energy from fat was unchanged between 1980 and 1990 but fell to $35 \%$ (about $76 \mathrm{~g} / \mathrm{d}$ ) in 2000 , alongside a $3 \%$ increase in percentage energy from starch (30\%). Percentage energy from non-milk extrinsic sugars remained above recommendations $(16 \%$; about $82 \mathrm{~g} / \mathrm{d})$. The number of overweight and obese children increased from $11 \%$ to $30 \%$ between 1980 and 2000. Positive changes have occurred in the Northumbrian adolescent diet but social inequalities, reported in previous surveys, remain.
\end{abstract}

Adolescents: Dietary trends: Macronutrients: Body mass index

Nutrition during adolescence is important for several reasons; first, because adolescence is a time of rapid growth and development and, second, because adolescents are beginning to show independence in food choice and increased consumption of food and drink away from home (Adamson et al. 1996). There has been concern that poor dietary habits formed in adolescence continue into adult life and affect future families (Department of Health, 1994). Health education aimed at addressing these concerns has increased over the past 20 years, with initiatives such as 'The Health of the Nation' (Department of Health, 1992) and 'Our Healthier Nation' (Department of Health, 1999) providing continued support. While healthy eating messages have been consistent in the UK during this time, the emphasis has changed from the rather negative call to reduce consumption of fats and sugars, to a more positive message to increase consumption of fresh fruit and vegetables (Department of Health, 1999). It is important to monitor changes in the diet and nutrient intake of adolescents, to help to inform public health strategy. There has also been concern that the prevalence of adolescent obesity has increased in the UK (Reilly et al. 1999; Gregory et al. 2000; Chinn \& Rona, 2001) and USA (Ogden et al. 2002) with serious consequences for health (Anonymous, 1983; National Audit Office, 2001). Since BMI is known to track from adolescence to adulthood (Guo \& Chumlea, 1999; National Audit Office, 2001), information on trends in obesity in adolescents is desirable.

Most of the information on the diets of adolescents in the UK comes from ad hoc regional surveys (Cook et al. 1973; Durnin et al. 1974; Nelson \& Naismith, 1979; Darke et al. 1980; Nelson et al. 1990; McNeill et al. 1991; Strain et al. 1994; Ruxton et al. 1996; Hackett et al. 1997). Two national surveys of British schoolchildren have been conducted in 1983 and 1997 (Department of Health, 1989a; Gregory et al. 2000). A decline in the proportion of energy from fat was observed, although slight changes in

\footnotetext{
Abbreviations: EAR, estimated average requirement; EEE, estimated energy expenditure; EI, energy intake; NMES, non-milk extrinsic sugars; NDNS, National Diet and Nutrition Survey; SOC, standard occupational classification.

* Corresponding author: Dr Ashley Adamson, fax + 44191222 5276, email a.j.adamson@ncl.ac.uk
} 
age groupings make comparisons difficult. Favourable changes in the diets of adolescents have also been recorded recently in the USA where fat intakes of children aged 1118 years have fallen from $39 \%$ in 1965 to $32 \%$ energy intake (EI) in 1994-6 (Cavadini et al. 2000).

An observational nutritional survey undertaken in south Northumberland in 1980 (Hackett et al. 1984a) was repeated in 1990 (Adamson et al. 1992). This was in order to assess changes in the diets of 11- to 12-year-old adolescents after a decade which included major national healthy eating recommendations for children (National Advisory Committee on Nutrition Education, 1983; Department of Health and Social Security, 1984; Department of Health 1989b). The results revealed that there was no change in some of the most important aspects of their diets. Fat and sugars remained constant, contributing 40 and $22 \%$, respectively, to EI, but there were some improvements with an increase in the intake of unavailable carbohydrate (Southgate fibre) between 1980 and 1990. The proportion of the children aged 11-12 years classified as overweight and obese, using the international adolescent cut-offs for 11.5-year-olds (Cole et al. 2000), increased from $11 \%$ to $17 \%$. The opportunity has been taken to repeat the dietary survey and measure BMI, using the same methods and in the same schools, in 2000.

\section{Subjects and methods}

The location of the study was the Morpeth, Ashington and Newbiggin area of south Northumberland. These areas were chosen, in the first study in 1980, to give a representative range of social classes (Hackett et al. 1984a). Permission was obtained from the County Education Authority and the study protocol was approved by the local research ethics committee. All children in school year seven (aged 11-12 years) attending seven middle schools in this locality were invited to participate, and a letter describing the study was sent to parents who were thereby asked to consent to their child taking part. Those who did not consent were not approached further.

The school, age group of children and the method of collecting information on dietary intake, height and weight were the same as described by Hackett et al. (1983, 1984a) and Adamson et al. (1992). On two occasions between November 1999 and July 2000, each child recorded, in a specifically designed pocket-size diary, all foods and drinks consumed during three consecutive days. Full instructions were given to groups of children, to each child individually shortly before they recorded their diet, and were provided in written form in the front of the diet diary. Children recorded the time of consumption, foods consumed, estimates in household measures of the quantities eaten and their bedtimes. Each child was then interviewed on the fourth day by one nutritionist to verify and enlarge on the information provided and to determine the place of purchase of each food item. By questioning, and with the aid of food models, a quantitative record of food intake was obtained (Hackett et al. 1983); colour photographs of food brands aided identification (Adamson et al. 1992). Over the two diaries, as many days of the week as possible were recorded for each child. The study period included all seasons of the year to account for any seasonal changes in intake. The order in which the schools were visited was reversed in the second survey in order to give a mid-point of dietary data collection of February 2000.

Since comparisons between the present study and the surveys conducted in 1980 and 1990 were important, the nutritionist undertaking the present study was trained in collecting dietary records and other aspects of the study by the nutritionist who undertook the 1990 survey, who, in turn, had been trained by the nutritionist who undertook the 1980 study (Adamson et al. 1992). This involved theoretical and field training in the same schools (but not with the same children) that were participating in the main study.

The height and weight of each child were measured in February 2000 (mid-point of study) in school using a vertical stadiometer (Soehnle; Chasmors Ltd, London, UK) and spring scales (Tanita; Chasmors Ltd), with jacket and shoes removed, as described by Hackett et al. (1984b). Height was measured to the nearest $10 \mathrm{~mm}$ and weight to the nearest $0.1 \mathrm{~kg}$. Date of birth and home postcode were obtained for each child in the school year from school records. In July 2000, the occupations of both parents (if available) of each child completing the study were sought by questionnaire to the child's home. Ethnicity was not measured in the present study; however from observation only six children were of non-white Caucasian origin in any one survey.

Each child's nutrient intake was calculated by a purposewritten program using supplements to McCance and Widdowson's The Composition of Foods. These were: (a) Cereal and Cereal Products (Holland et al. 1988); (b) Milk Products and Eggs (Holland et al. 1989); (c) Immigrant Foods (Tan et al. 1985); (d) Vegetables, Herbs and Spices (Holland et al. 1991); (e) Fruit and Nuts (Holland et al. 1992a); (f) Vegetable Dishes (Holland et al. 1992b); (g) Fish and Fish Products (Holland et al. 1993); (h) Miscellaneous Foods (Chan et al. 1994); (i) Meat, Poultry and Game (Chan et al. 1995); (j) Meat Products and Dishes (Chan et al. 1996). In addition, some food composition information was obtained from manufacturers. Non-milk extrinsic sugars (NMES) were determined according to the method previously reported (Rugg-Gunn et al. 1986). The mean of the $6 \mathrm{~d}$ record was calculated for each child. These data were compared with data collected in 1980 (Hackett et al. 1984a) and 1990 (Adamson et al. 1992), and with current dietary reference values for the UK (Department of Health, 1991). The composition of some foods has changed over time; for example, the fat content of some meats has fallen with changes in animal husbandry. At each study (1980, 1990 and 2000) the most extensive and up-to-date food tables available at the time of study were used. That is, nutrient intakes were analysed using contemporary food composition tables since these were most likely to reflect the nutrient composition of the food consumed at that time. At each study foods, for which no composition data were available, were added either from alternative analyses (for example, MRC Dunn Nutrition Unit in 1990) or from manufacturers' data or by dissection of foods into constituent items for which codes are available. The validity of the method of collecting nutrient data was investigated by 
comparing the reported EI with the predicted BMR and estimated energy expenditure (EEE) to estimate the number of likely under-reporters or low-energy consumers. Predicted BMR was calculated using prediction formulas (boys, $0.074 \times$ weight $(\mathrm{kg})+2.754$; girls, $0.056 \times$ weight $(\mathrm{kg})+2.898)$ (Schofield, 1985). In the absence of any data on physical activity the EEE of the children was determined by multiplying predicted BMR by 1.56 and 1.48 for boys and girls, respectively (Department of Health, 1991). The reliability of the data in 1980 was investigated by Hackett et al. (1983). BMI was calculated as weight $(\mathrm{kg}) / \mathrm{height}$ $(\mathrm{m})^{2}$. BMI cut-offs used to define overweight and obesity were based on the new international definitions for 11.5year-olds (Cole et al. 2000). For the purpose of comparison, these definitions were used in 2000 and applied retrospectively to the 1980 and 1990 data. While this analysis does not take into account any secular changes in body composition or frame size, the potential effect of any secular change over 20 years was judged to be minor. Age was calculated to February 2000, the mid-point of the study, and the time when height and weight were measured.

The system of classifying occupational class in the UK has changed since the previous surveys in 1980 and 1990, and so there is difficulty in comparing the current (Office of National Statistics, 2000) classification with the previous system (Registrar General, 1980). Therefore the Occupational Information Unit of the Office of National Statistics classified parental occupations in the present study using the 'simplified social class' method based on the standard occupational classification (SOC) of 1990 (Office of Population Censuses and Surveys, 1990; T Staples, Occupational Information Unit, personal communication). If both parents' occupations were recorded, the 'higher' of the two took preference. Children were grouped into social groups 'high' (social classes I + II), 'middle' (III), 'low' (IV + V) and unclassified. The subjects in the 2000 survey were also classified according to the most recent system (Office of National Statistics, 2000) to assist analysis by social group in future surveys and help comparisons with other contemporary surveys. Townsend deprivation scores were derived from the postal code addresses of all children eligible to participate (Townsend et al. 1988). Townsend scores were divided into quintiles based on England and Wales and expressed as quintiles of deprivation.

Descriptive data from the 2000 survey are presented as means and standard deviations. Data from all three surveys were combined so that differences in nutrient data based on the three main categorical variables, i.e. study $(1980,1990$, 2000), sex and social class (high, middle, low), could be examined using multiple regression (STATA version 7; StataCorp, 2001). Interactions between these variables were also considered. The third part of the analyses compared results from the present 2000 study with results from the most recent UK national study, carried out in 1997 (Gregory et al. 2000).

\section{Results}

\section{Participating children}

In the survey in 2000, $450(68 \%)$ of the 661 eligible children volunteered to participate in the study, of which 424
(94\%) completed all aspects. In the 1980 and 1990 surveys, 784 and 546 children were eligible to participate, respectively. In 2000, of the 424 children, 196 (46\%) were boys, a similar distribution to that recorded in the surveys in 1980 and 1990. Few children withdrew $(0.5 \%)$ and a total of $3.9 \%$ were excluded for reasons outlined in Table 1 . The $424(64 \%)$ children completing all aspects of the study compares with 405 (51\%) in 1980 and 379 (69\%) in 1990.

Table 2 shows the social-class grouping (Office of Population Censuses and Surveys, 1990) and the SOC by parental occupation for the participating children. Almost one half of the participating children $(47 \%)$ were within the high-social-class group, $28 \%$ in the middle social group and $14 \%$ in the low social group. These percentages can be compared with 36, 31 and $18 \%$ in 1990, and 21, 43 and $29 \%$ in the 1980 study. The majority of children (in 2000) were in the higher SOC (Office of National Statistics, 2000) groups. Table 2 also shows the Townsend index of deprivation for all eligible children. The postcodes of $96 \%$ of all the children in year 7 were obtained. The distribution of children amongst the quintiles of the Townsend index of deprivation was in agreement with the socialgroup distribution, i.e. fewer children within the higher deprivation quintiles participated in the study than in the least deprived quintiles. However, there was no significant difference in the distribution by quintile of Townsend index of deprivation of $96 \%$ of eligible children and the distribution of participating children suggesting that, at least with respect to material deprivation, the children participating were representative of all 11- to 12-year-old children in these seven schools.

Dietary interviews were carried out during school hours with fewer interviewed on Thursdays and Fridays. The distribution of the days surveyed was similar for all three surveys (Table 3$)$. The majority $(68 \%)$ of dietary intake was recorded on schooldays. On $1 \%$ of days, the child was ill when recording dietary intake.

Age was calculated for the time that height and weight were measured (Table 4). Both boys and girls were $0.05 \mathrm{~m}$ taller and approximately $6 \mathrm{~kg}$ heavier in 2000 compared with 1980, although these measurements were made 2 months later in the 2000 survey. Between 1980 and 2000, the proportion of overweight children (using the international adolescent cut-offs; Cole et al. 2000) almost trebled from $11 \%$ to $30 \%$ (Table 4 ). In 2000, one in three children were overweight and one in fourteen were obese.

Table 1. Number of 11- to 12-year-old children in the study in seven middle schools in south Northumberland in 2000

\begin{tabular}{lccc}
\hline & $\begin{array}{c}\text { Number } \\
\text { of children }\end{array}$ & of total & $\begin{array}{c}\text { Percentage } \\
\text { of volunteers }\end{array}$ \\
\hline Eligible children & 661 & 100 & - \\
No. consented & 450 & $68 \cdot 1$ & 100 \\
Total incomplete diaries & 26 & 3.9 & $5 \cdot 8$ \\
Withdrew & 3 & 0.5 & 0.7 \\
Changed schools & 5 & $0 \cdot 8$ & $1 \cdot 2$ \\
Lost diary or absentism & 17 & $2 \cdot 6$ & 4.0 \\
Died & 1 & 0.2 & 0.2 \\
Completed all aspects & 424 & $64 \cdot 1$ & 94.2 \\
\end{tabular}


Table 2. All 11- to 12-year-old Northumbrian children $(n$ 424) in the 2000 study grouped into social-class groupings by parental occupation (Office of Population Censuses and Surveys, 1990), standard occupational classification (SOC; Office of National Statistics, 2000) and index of deprivation (Townsend et al. 1988)

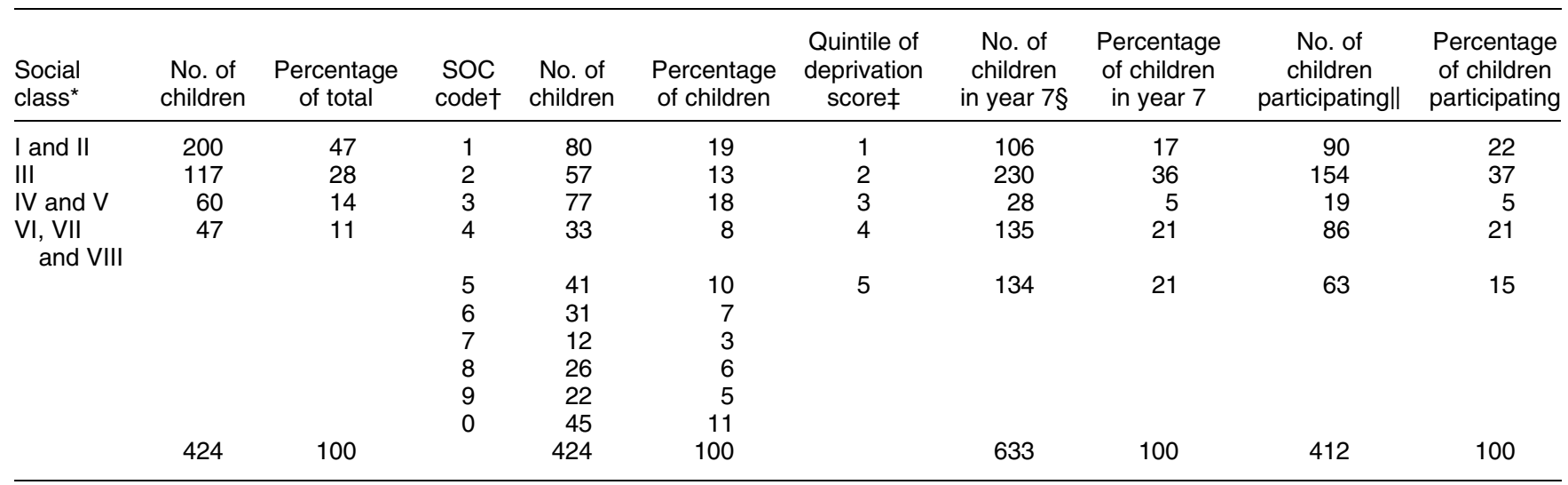

* Social class: I and II, high; III, middle; IV and V, low; VI, VII and VIII, unclassified.

†SOC: 1, senior managers and professionals; 2, professional; through to 8, process, plant and machine operatives; 9 , elementary occupations; 0 , unclassified. $\ddagger$ Deprivation score: 1 , least deprived; 5 , most deprived.

$\S$ Postcode not available for twenty-eight out of the 661 children in year 7 .

|| Postcode not available for twelve out of the 424 participating children.

Table 3. Distribution of days surveyed (11- to 12-year-old south Northumbrian subjects $(n 424) \times 6 d)$ in 2000 compared with the percentage distribution in the 1990 and 1980 studies

\begin{tabular}{|c|c|c|c|c|}
\hline \multirow{2}{*}{$\begin{array}{l}\text { Study... } \\
\text { Day of week }\end{array}$} & \multicolumn{2}{|r|}{2000} & \multirow{2}{*}{$\frac{1990}{\text { Percentage of total }}$} & \multirow{2}{*}{$\frac{1980}{\text { Percentage of total }}$} \\
\hline & Number & Percentage of total & & \\
\hline Monday & 427 & 17 & 19 & 21 \\
\hline Tuesday & 461 & 18 & 20 & 19 \\
\hline Wednesday & 371 & 15 & 13 & 13 \\
\hline Thursday & 246 & 10 & 8 & 6 \\
\hline Friday & 247 & 9 & 6 & 8 \\
\hline Saturday & 384 & 15 & 14 & 14 \\
\hline Sunday & 408 & 16 & 20 & 19 \\
\hline Total & 2544 & 100 & 100 & 100 \\
\hline
\end{tabular}

Table 4. Height, weight, body mass index, and age at the time of measurement of the 11- to 12-year-old south Northumbrian boys and girls who participated in the surveys in 1980, 1990 and 2000

(Mean values and standard deviations)

\begin{tabular}{|c|c|c|c|c|c|c|c|c|c|c|c|c|}
\hline \multirow{3}{*}{$\begin{array}{l}\text { Sex... } \\
\text { Study... }\end{array}$} & \multicolumn{6}{|c|}{ Boys } & \multicolumn{6}{|c|}{ Girls } \\
\hline & \multicolumn{2}{|c|}{1980} & \multicolumn{2}{|c|}{1990} & \multicolumn{2}{|c|}{2000} & \multicolumn{2}{|c|}{1980} & \multicolumn{2}{|c|}{1990} & \multicolumn{2}{|c|}{2000} \\
\hline & Mean & SD & Mean & SD & Mean & SD & Mean & SD & Mean & SD & Mean & SD \\
\hline No. of subjects & 183 & & 184 & & 196 & & 212 & & 195 & & 228 & \\
\hline Age (years; months) & $11 ; 6 \cdot 6^{*}$ & 0.29 & $11 ; 6 \cdot 1^{*}$ & 0.29 & $11 ; 10 \cdot 8 \dagger$ & 0.30 & $11 ; 6 \cdot 7^{\star}$ & 0.30 & $11 ; 6 \cdot 8^{*}$ & 0.28 & $11 ; 10.8 \dagger$ & 0.30 \\
\hline Height (m) & 1.46 & 0.07 & 1.47 & 0.07 & 1.51 & 0.07 & 1.47 & 0.07 & 1.50 & 0.07 & 1.52 & 0.08 \\
\hline Weight (kg) & 39.02 & $7 \cdot 75$ & 40.46 & 8.82 & $45 \cdot 41$ & $10 \cdot 24$ & 39.88 & 8.05 & 41.93 & 8.85 & $46 \cdot 55$ & 10.56 \\
\hline $\mathrm{BMI}\left(\mathrm{kg} / \mathrm{m}^{2}\right)$ & $18 \cdot 15$ & $2 \cdot 57$ & 18.56 & 3.00 & $19 \cdot 69$ & 3.48 & $18 \cdot 33$ & 2.75 & 18.63 & 3.09 & 19.95 & 3.46 \\
\hline Overweightł (\%) & 11 & & 17 & & 27 & & 12 & & 17 & & 33 & \\
\hline Obese $\neq(\%)$ & 2 & & 3 & & 8 & & 1 & & 3 & & 6 & \\
\hline
\end{tabular}

* Age at commencement of study (December).

† Age at mid-point of study (February).

$\ddagger$ Calculated using international adolescent cut-offs for 11.5-year olds (Cole et al. 2000).

\section{Macronutrient intakes}

The mean macronutrient intakes for boys and girls in each of the three surveys are shown in Table 5. Multiple regression analyses revealed that mean EI were 0.68 (95\% CI $0.48,0.87)$ MJ lower in girls than boys
$(P<0 \cdot 0005)$. EI fell between 1980 and 1990 by $0.18 \mathrm{MJ}$, and by $0.52 \mathrm{MJ}$ between 1980 and $2000 \quad(P<0.0001$; Tables 5, 6 and 7). In 1980, the percentage of boys with EI below the estimated average requirement (EAR) of 9.27 MJ (Department of Health, 1991) was highest in the low social group; this trend was reversed in 1990 and 
2000. In 2000, $72 \%$ of high-social-group boys reported EI below the EAR. A lower proportion of girls than boys, from all social groups and in all surveys, had EI below the EAR (7.72 MJ) but the proportion of girls reporting EI below the EAR in 2000 was higher than in the previous surveys, particularly amongst the high-social-group girls $(62 \%)$.

Sex and survey had statistically significant effects on protein intake but the effect of social class was not significant $(P=0.09$; Tables 5, 6 and 7). Girls consumed, on average, 7.8 (95\% CI $6.14,9.18)$ g less protein than boys $(P<0.0005)$ and intakes increased between the surveys $(P=0.038)$. Fat intakes were $5.1(95 \%$ CI $2.7,7.5) \mathrm{g}$ lower in girls than in boys $(P<0.0005)$. The general level of fat intake was lower in 2000 than in the earlier surveys. However, the nature of the difference varied with social class (test for interaction, $P=0.0004$; Fig. 1(a)). Carbohydrate intakes differed between the sexes $(P<0.0005)$, with boys consuming 22.6 (95\% CI 15.6, 29.6) $\mathrm{g}$ more than girls. Intakes of starch increased significantly between 1980 and $2000(P<0 \cdot 0005)$ and boys consumed $16.2(95 \%$ CI $12.3,20 \cdot 0) \mathrm{g}$ more starch than girls $(P<0.0005$; Table 5). There was also a strong socialclass effect $(P<0 \cdot 0005)$; high-social-class children consumed $4.2 \mathrm{~g}$ more starch than the middle-social-class children, and middle-social-class children consumed $4.2 \mathrm{~g}$ more starch than the low-social-class children. NMES intakes were 4.9 (95\% CI $0.3,9.7) \%$ higher in boys than in girls $(P=0 \cdot 035)$. Intake of NMES increased from 1980 to 1990 but decreased from 1990 to 2000 $(P=0.0005)$. Unavailable carbohydrate (Southgate fibre; Wenlock et al. 1985) intakes were $1.3(95 \%$ CI $0.8,1.8) \mathrm{g}$ lower in girls than in boys $(P<0 \cdot 0005)$. Between 1980 and 1990, unavailable carbohydrate increased by $1.8 \mathrm{~g}$, and between 1980 and 2000 intakes increased by $2.1 \mathrm{~g}$ $(P<0 \cdot 0005)$. NSP (Englyst et al. 1989) was measured in 1990 and 2000 only; as with unavailable carbohydrate, intakes of NSP were $0.9(95 \%$ CI $0.4,1.3) \mathrm{g}$ higher in boys and increased from 1990 to $2000(P<0.0005$ for both variables).
No differences were found in NSP intakes between social classes $(P=0.79)$, but NSP intakes increased between 1990 and $2000(P<0 \cdot 0005)$.

No change in percentage energy derived from fat was evident between 1980 and 1990, but this decreased between 1990 and 2000 from $39.3 \%$ to $34.4 \%$ for boys and from $40.1 \%$ to $35.2 \%$ for girls (Fig. 1 (b)). There was clear evidence $(P=0 \cdot 012)$ that the difference between social classes differed between the surveys. In 1980 there was little difference between social groups in percentage energy from fat and by 2000 the percentage energy from fat was lower by $2 \%$ units in the high-social-class children compared with the lower-social-class children. The recommendation for the proportion of energy from fat $35 \%$ or below) was met by more boys in 2000 than in the previous surveys, with boys in the high social group more likely to meet requirements (61\%; Table 6). The number of girls meeting recommendations of percentage energy from fat was only 3\% in the high social group in 1980 compared with $50 \%$ in 2000 (Table 7). The percentage energy from protein increased significantly $(P<0.0005)$ between the surveys (Table 8$)$. The effects of sex and social class were also statistically significant $(P<0 \cdot 0005$; data not shown). Mean percentage energy from carbohydrate fell by 0.6 (95\% CI $0.04,1.24) \%$ between 1980 and 1990 but increased by 3.8 (95\% CI 3.26, 4.41) \% from 1980 to 2000; these differences were both statistically significant $(P<0 \cdot 00001)$. There was no statistically significant effect of sex or social class. A sex $\times$ survey interaction $(P=0.04)$ and a survey $\times$ social class interaction $(P=0.016)$ was observed for percentage energy from starch intakes; boys had higher percentage energy from starch intakes than girls in all three surveys and intakes were similar between 1980 and 1990 but increased between 1990 and 2000. As social class fell, percentage energy from starch increased in 1980 and 1990 but in 2000 all social classes were consuming similar intakes $(30 \%$; data not shown). Percentage energy from NMES increased significantly between 1980 and 1990 and fell marginally, but significantly, between 1990 and $2000(P<0 \cdot 0005)$.

Table 5. Daily intakes of energy, macronutrients, unavailable carbohydrate and non-starch polysaccharides of the 11- to 12-year-old south Northumbrian boys and girls who participated in the surveys in 1980, 1990 and 2000

(Mean values and standard deviations)

\begin{tabular}{|c|c|c|c|c|c|c|c|c|c|c|c|c|}
\hline \multirow{3}{*}{$\begin{array}{l}\text { Sex... } \\
\text { Study... }\end{array}$} & \multicolumn{6}{|c|}{ Boys } & \multicolumn{6}{|c|}{ Girls } \\
\hline & \multicolumn{2}{|c|}{1980} & \multicolumn{2}{|c|}{1990} & \multicolumn{2}{|c|}{2000} & \multicolumn{2}{|c|}{1980} & \multicolumn{2}{|c|}{1990} & \multicolumn{2}{|c|}{2000} \\
\hline & Mean & SD & Mean & SD & Mean & SD & Mean & SD & Mean & SD & Mean & SD \\
\hline No. of subjects & 193 & & 184 & & 196 & & 212 & & 195 & & 228 & \\
\hline Energy (MJ) & $8 \cdot 90$ & 1.54 & $8 \cdot 61$ & 1.79 & 8.45 & 1.90 & $8 \cdot 27$ & 1.53 & $8 \cdot 25$ & 1.9 & $7 \cdot 60$ & 1.57 \\
\hline Protein (g) & $61 \cdot 2$ & $12 \cdot 1$ & $62 \cdot 1$ & $13 \cdot 1$ & $62 \cdot 5$ & $15 \cdot 0$ & $53 \cdot 8$ & $10 \cdot 9$ & $57 \cdot 4$ & $13 \cdot 4$ & $53 \cdot 6$ & $12 \cdot 9$ \\
\hline Carbohydrate (g) & 271.5 & 49.5 & $263 \cdot 8$ & $65 \cdot 2$ & $277 \cdot 2$ & $65 \cdot 1$ & $251 \cdot 6$ & $53 \cdot 1$ & $251 \cdot 7$ & $62 \cdot 1$ & $249 \cdot 0$ & $53 \cdot 0$ \\
\hline Starch (g) & $152 \cdot 1$ & $32 \cdot 2$ & $145 \cdot 7$ & 34.0 & $158 \cdot 6$ & $36 \cdot 3$ & $136 \cdot 6$ & $30 \cdot 0$ & $132 \cdot 5$ & $34 \cdot 7$ & $144 \cdot 6$ & $32 \cdot 4$ \\
\hline NMES (g) & 81.5 & $25 \cdot 0$ & $89 \cdot 3$ & $38 \cdot 1$ & $86 \cdot 8$ & 33.0 & $79 \cdot 9$ & $29 \cdot 1$ & $91 \cdot 2$ & $33 \cdot 1$ & $76 \cdot 2$ & $26 \cdot 2$ \\
\hline $\begin{array}{l}\text { Unavailable } \\
\text { carbohydrate* }(\mathrm{g})\end{array}$ & $13 \cdot 9$ & 3.9 & $15 \cdot 9$ & $4 \cdot 7$ & $16 \cdot 3$ & $5 \cdot 3$ & $13 \cdot 0$ & $3 \cdot 6$ & $14 \cdot 8$ & 3.9 & $14 \cdot 8$ & $4 \cdot 0$ \\
\hline NSP† (g) & NA & & $9 \cdot 4$ & $3 \cdot 2$ & $11 \cdot 1$ & $3 \cdot 3$ & NA & & $9 \cdot 0$ & 2.7 & $10 \cdot 2$ & 2.7 \\
\hline
\end{tabular}

NMES, non-milk extrinsic sugars; NA, data not available in 1980.

${ }^{\star}$ Estimated by Southgate method (Wenlock et al. 1985).

†Estimated by Englyst method (Englyst et al. 1989). 



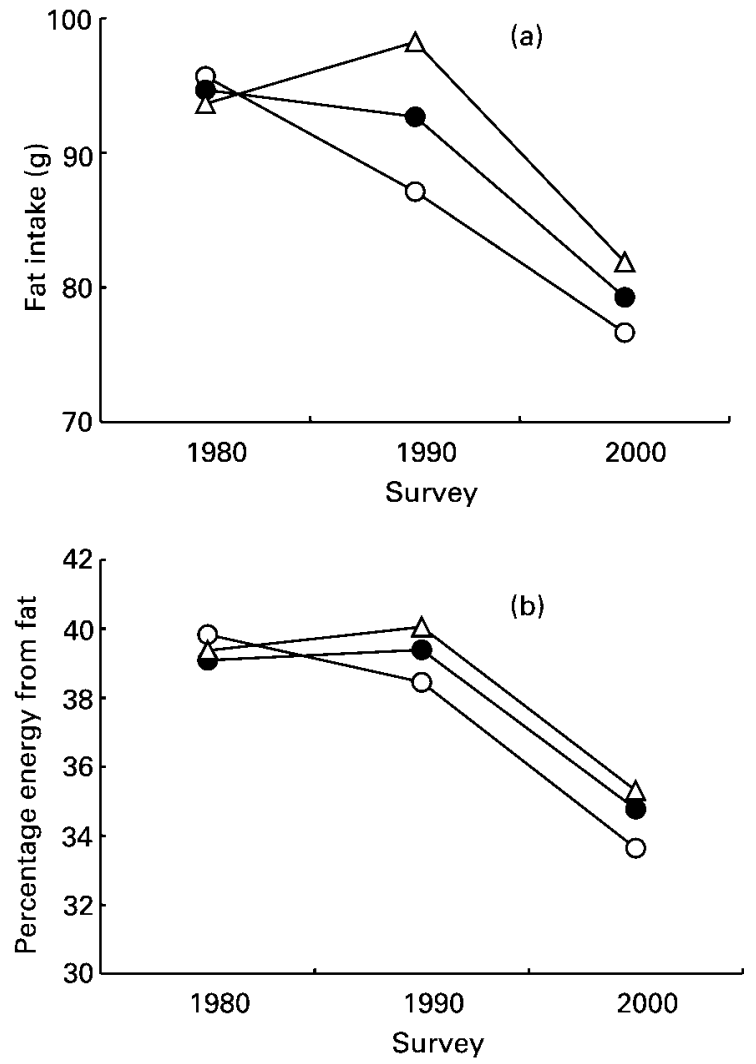

Fig. 1. Changes in (a) absolute fat intake and (b) percentage energy from fat for participating children by social class (high $(\bigcirc)$, middle $(\bullet)$ and low $(\Delta)$ ) between 1980 and 2000.

There were no significant differences observed between social groups.

\section{Energy intakes and estimated energy expenditure}

The EI:BMR ratios were significantly higher in girls than in boys $(P=0.04$; Table 9$)$. EI:BMR fell $(P<0 \cdot 001)$ between 1980 and 2000 in boys and girls (1.57 to 1.38 , and 1.61 to 1.38 , respectively). The EI:EEE ratios were 0.89 and 0.93 in boys and girls in 2000 .

Children from all social groups were heavier in 2000 compared with 1990 and 1980 (Table 10), although they were on average 2 months older at the time of measurement in 2000. BMI increased between 1980 and 2000 $(P<0.001)$. No sex or social class differences were found in BMI. The EI:BMR ratio decreased for both sexes and all social groups between the surveys. Boys in the low social group had higher EI:BMR ratios than those in other social groups, although this was not significant $(P=0.08)$. For boys only, EI:EEE was $1 \cdot 01,0.97$ and 0.89 for the surveys carried out in 1980, 1990 and 2000, respectively. For girls, the EI:EEE for 1980, 1990 and 2000 was $1.09,1.08$ and 0.93 , respectively (both sexes; $P<0.01$ ) (Table 9). Between 1980 and 2000, the number of children with EI:BMR less than $1 \cdot 1$ (Goldberg et al. 1991) increased significantly $(P<0 \cdot 001)$. For 1980,1990 and 2000, the percentage of boys with EI:BMR below 1.1 was 6,15 and $23 \%$, respectively; for girls, 3, 14 and
$18 \%$, respectively. The largest percentage of probable under-reporting or low-energy consumers was found in the middle-social-group boys $(27 \%)$ and low-socialgroup girls $(24 \%)$ (Table 10). Possible over-reporting or high-energy consumers (EI:BMR greater than $2 \cdot 11$; Sanchez-Castillo et al. 2001) was 6, 7 and $2 \%$ for 1980 , 1990 and 2000, respectively.

\section{Discussion}

The present study showed a substantial fall in fat intake (equivalent to $5 \% \mathrm{EI}$ ) by young Northumberland adolescents between 1990 and 2000, following a period of no change between 1980 and 1990. The fall in EI from fat was matched by a rise in the percentage energy from starch, while percentage energy from NMES intake showed a slight decline. While the decline in EI observed between 1980 and 1990 continued from 1990 to 2000, the proportion of young adolescents classified as overweight and obese increased from $11 \%$ to $30 \%$ between 1980 and 2000, of which $7 \%$ were obese in 2000. This apparent paradox must be due, at least in part, to an increase in suspected low-energy reporters as indicated earlier (p. 327).

\section{Dietary survey methodology}

The methods used were similar in the three surveys; these were based on two dietary records, each of $3 \mathrm{~d}$, during the school year. Although the nutritionist was different in each survey, training and calibration with the previous nutritionist took place before the 1990 and 2000 surveys (Adamson et al. 1992). The most recent food composition tables were used in each survey. The reliability of data collected by this method involving two surveys of $3 \mathrm{~d}$ each has been discussed previously and was estimated to be 0.59 (Hackett et al. 1983). Since group means were presented, this value was considered adequate. The validity of the method in terms of the measurement of EI was assessed by examination of the reported EI:BMR ratio.

The reported EI:BMR ratio fell from 1.46 in 1990 to 1.38 in 2000 . Although it is probable that physical activity fell between 1990 and 2000 (Prentice \& Jebb, 1995), the possibility of under-recording of EI must be acknowledged. The potential problem of under-recording, especially by obese adolescents (Bandini et al. 1990) and adults (Schoeller, 1990; Macdiarmid \& Blundell, 1997), is well recognised. While, in the absence of any measure of activity, there is no direct evidence that under-recording was more prevalent in the 2000 survey than in the two previous surveys; this is likely to be responsible, at least in part, for the fall in EI reported. Table 11 presents EI and percentage energy from fat, protein and carbohydrate reported by children with reported EI $>1.1 \times$ BMR ('valid reporters') and those with reported EI $<1.1 \times \mathrm{BMR}$ (low-energy reporters). These data show that while the difference between these groups in reported EI is evident and EI for 'valid reporters' appears to have changed little over the three surveys, the finding that percentage energy derived from fat has fallen is confirmed. The slight fall in percentage energy from NMES is also apparent in the 'valid reporters'. Comparisons of height and weight of these children were 
Table 8. Percentage contributions of macronutrients to total energy intake of the 11- to 12-year-old south Northumbrian boys and girls who participated in the surveys in 1980, 1990 and 2000

(Mean values and standard deviations)

\begin{tabular}{|c|c|c|c|c|c|c|c|c|c|c|c|c|}
\hline \multirow{3}{*}{$\begin{array}{l}\text { Sex... } \\
\text { Study... }\end{array}$} & \multicolumn{6}{|c|}{ Boys } & \multicolumn{6}{|c|}{ Girls } \\
\hline & \multicolumn{2}{|c|}{1980} & \multicolumn{2}{|c|}{1990} & \multicolumn{2}{|c|}{2000} & \multicolumn{2}{|c|}{1980} & \multicolumn{2}{|c|}{1990} & \multicolumn{2}{|c|}{2000} \\
\hline & Mean & SD & Mean & SD & Mean & SD & Mean & $\mathrm{SD}$ & Mean & SD & Mean & SD \\
\hline No. of subjects & 193 & & 184 & & 196 & & 212 & & 195 & & 228 & \\
\hline Fat & $39 \cdot 3$ & 3.6 & $39 \cdot 3$ & $4 \cdot 3$ & 34.4 & $3 \cdot 6$ & $40 \cdot 3$ & 3.4 & $40 \cdot 1$ & $3 \cdot 6$ & $35 \cdot 2$ & $3 \cdot 8$ \\
\hline Protein & $11 \cdot 7$ & 1.4 & $12 \cdot 4$ & $2 \cdot 1$ & $12 \cdot 7$ & $2 \cdot 0$ & $11 \cdot 1$ & 1.6 & 11.9 & $1 \cdot 8$ & $12 \cdot 1$ & 1.9 \\
\hline Carbohydrate & $48 \cdot 9$ & 3.8 & $48 \cdot 2$ & $4 \cdot 7$ & $52 \cdot 6$ & $4 \cdot 0$ & 48.6 & 3.9 & $48 \cdot 0$ & 3.9 & $52 \cdot 5$ & 3.9 \\
\hline Starch & $27 \cdot 4$ & $3 \cdot 6$ & $27 \cdot 2$ & $4 \cdot 1$ & $30 \cdot 3$ & 3.9 & $26 \cdot 5$ & 3.7 & $25 \cdot 8$ & 3.4 & $30 \cdot 6$ & 3.7 \\
\hline NMES & $14 \cdot 7$ & 3.7 & $16 \cdot 3$ & $5 \cdot 0$ & $16 \cdot 3$ & $4 \cdot 3$ & $15 \cdot 3$ & $4 \cdot 2$ & $17 \cdot 5$ & $4 \cdot 1$ & $16 \cdot 0$ & $4 \cdot 1$ \\
\hline
\end{tabular}

NMES, non-milk extrinsic sugars.

slightly complicated by measurements being made 2 months later in the school year in the 2000 survey than in the 1980 and 1990 surveys. However, reference to national growth charts (Freeman et al. 1995) revealed that only a small proportion of the increase in weights between 1990 and 2000 could be due to the difference of 2 months in age at the time of measurement.

The substantial rise in BMI could not be due to the difference in age at the time of anthropometric measurement. There has been debate about the appropriateness of using BMI in surveys of children (Power et al. 1997; Bellizzi \& Dietz, 1999; Prentice \& Jebb, 2001). Nevertheless, BMI is widely accepted as a reasonable measure of fatness in children (Cole et al. 1995; Bellizzi \& Dietz, 1999; Dietz \& Bellizzi, 1999; Malina \& Katzmarzyk, 1999; Chinn \& Rona, 2001). The recently published international child and adolescent definition was used to determine overweight and obesity prevalence in these children from Northumberland (Cole et al. 2000). These standard definitions of adolescent overweight and obesity are based on values that correspond to a BMI of 25 and 30 at age 18 years (Bellizzi \& Dietz, 1999; Cole et al. 2000). These recently developed standard definitions have been applied retrospectively to the 1980 and 1990 to allow comparison between the three surveys.
The area of the study was chosen to yield subjects from a wide range of social groups (Hackett et al. 1983). Just under $70 \%$ of the school year (eligible subjects) volunteered and completed all aspects of the study in 2000, a similar percentage to that reported in 1990 (Adamson et al. 1992). Unlike the previous surveys, postcodes were known for $96 \%$ of eligible children in 2000, enabling a comparison to be made of social profiles of eligible and completing subjects (Table 2). There was a slight tendency for children living in areas with a low deprivation index to be over-represented and the children living in areas with a high deprivation index to be under-represented, but this difference was not significant $\left(\chi^{2}\right.$ test; $\left.P=0 \cdot 086\right)$. The sample as a whole was not significantly different from the deprivation distribution of Northumberland (Office of Population Censuses and Surveys, 1993).

Inspection of data for all three surveys using the Registrar General's classification (1980) revealed an increasing tendency for the subjects to belong to social classes I and II ('high'-social-class group) and fewer to belong to social classes IV and V ('low'-social-class groups) (Table 2). However, the distribution in the 2000 survey was dissimilar to the social-class distribution for the UK and Northumberland area which was determined in 1991 (high social group $32 \%$, middle social group $44 \%$ and

Table 9. Energy intake (EI):predicted basal metabolic rate ratio (together with the percentage of children with ratio values below 1.1), and the El:estimated energy expenditure (EEE) ratio for 11- to 12-year-old south Northumbrian boys and girls in the 1980, 1990 and 2000 studies

(Mean values)

\begin{tabular}{|c|c|c|c|c|c|c|c|c|c|}
\hline & \multirow[b]{2}{*}{$n$} & \multirow[b]{2}{*}{ Wt (kg) } & \multicolumn{2}{|c|}{$\begin{array}{l}\text { Predicted BMR* } \\
\text { (MJ) }\end{array}$} & \multirow[b]{2}{*}{ EEE† (MJ) } & \multirow[b]{2}{*}{ El (MJ) } & \multicolumn{2}{|c|}{ El:BMR } & \multirow[b]{2}{*}{ El:EEE } \\
\hline & & & Value & $95 \% \mathrm{Cl}$ & & & Mean & $\%$ below 1.1 & \\
\hline \multicolumn{10}{|l|}{ Boys } \\
\hline 1980 & 193 & $39 \cdot 0$ & $5 \cdot 64$ & $5 \cdot 56,5 \cdot 72$ & $8 \cdot 80$ & 8.90 & 1.57 & 6 & 1.01 \\
\hline 1990 & 184 & $40 \cdot 5$ & $5 \cdot 75$ & $5 \cdot 65,5 \cdot 85$ & 8.97 & $8 \cdot 61$ & 1.51 & 15 & 0.97 \\
\hline 2000 & 196 & $45 \cdot 4$ & $6 \cdot 11$ & $6 \cdot 00,6 \cdot 22$ & 9.53 & $8 \cdot 45$ & 1.38 & 23 & 0.89 \\
\hline \multicolumn{10}{|l|}{ Girls } \\
\hline 1980 & 212 & 39.9 & $5 \cdot 13$ & $5 \cdot 07,5 \cdot 19$ & 7.59 & $8 \cdot 27$ & 1.61 & 3 & 1.09 \\
\hline 1990 & 195 & 41.9 & $5 \cdot 25$ & $5 \cdot 17,5 \cdot 32$ & $7 \cdot 76$ & $8 \cdot 25$ & 1.60 & 14 & 1.08 \\
\hline 2000 & 228 & $46 \cdot 5$ & $5 \cdot 50$ & $5.43,5.58$ & $8 \cdot 14$ & $7 \cdot 60$ & $1 \cdot 38$ & 18 & 0.93 \\
\hline
\end{tabular}

*Predicted from body weight; Schofield equation for boys and girls of 10-18 years (Schofield, 1985).

†EEE is determined by multiplying predicted BMR by 1.56 in boys and 1.48 in girls (Department of Health, 1991). 
Diets and body mass index of adolescents
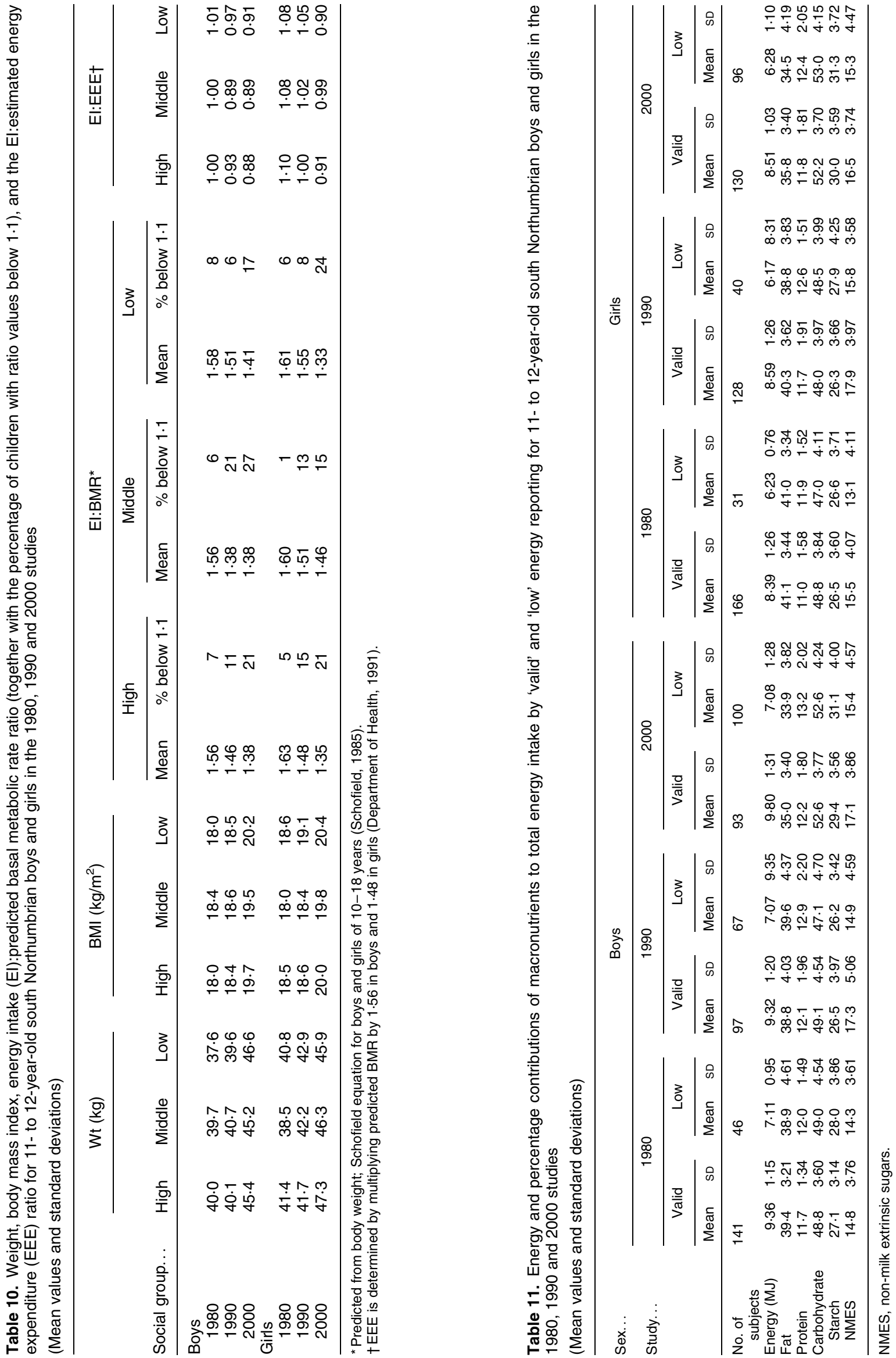
low social group 24\%; Office of Population Censuses and Surveys, 1993). UK and Northumberland social-class data were obtained using the SOC 1990 system (Office of Population Censuses and Surveys, 1990). The differences in social-class distribution may be due to the different time points at which social class was measured, 1991 and 2000 , or a genuine shift in social-class distribution. Alternatively, the schools recruited in all three studies may not be representative of the whole Northumberland area. Detecting social inequalities in dietary intake and trends over time in these studies were important aspects of the present work. The numbers of subjects included in these decennial surveys were sufficient to detect differences and trends, and changes over time in social class were accounted for in our models.

\section{Dietary intakes}

The fall in reported EI observed over the past two decades is in agreement with national findings (Department of Health, 1989a; Gregory et al. 2000). The two national studies, 'Diets of British School Children' (Department of Health 1989a) and 'National Diet and Nutrition Survey: Young People aged 4 to 18 Years' (NDNS; Gregory et al. 2000), were completed in 1983 and 1997, respectively and EI reported in 1997 were similar to results in the present study conducted in 2000. This decrease in reported EI may have begun earlier, since Durnin et al. (1974) found a decrease of 0.9 MJ in EI of Scottish 14year-olds between 1964 and 1971. Whitehead et al. (1982) reviewed dietary surveys of children and adolescents and found a long-term downward trend in total EI. EI from the present 2000 study were below EAR (Department of Health, 1991), as has been observed in other studies in the UK (Cook et al. 1973; Durnin et al. 1974; Department of Health, 1989a; Nelson et al. 1990; Gregory et al. 2000). Northern Irish 12-year-olds consumed EI above recommendations (Department of Health, 1991; Strain et al. 1994), although median intakes were reported due to a skewed distribution of intakes in this study. EI higher than recommendations were expected for this group of Northern Irish adolescents as the mean weight of the sample was higher than that used when energy requirements were calculated by the Department of Health, (1991). From the present study, children in the high social group were less likely to meet the EAR for energy than children in the low social group. In the absence of data on physical activity the reasons for this are unclear; there were no significant social-group differences in BMI. Boys in the low social group had a higher EI:BMR ratio than children in other groups $(P=0 \cdot 08)$. While this difference did not reach significance it may be that low-socialgroup boys had higher levels of activity. The lower levels of EI reported by higher-social-group children cannot be explained entirely by low energy reporting although this may play a part. In 2000 the levels of low energy reporting by boys were highest in the middle $(27 \%)$ but lowest in the low social group (17\%), while for girls higher levels of low energy reporting were found for the high- $(21 \%)$ and low-social-group girls
(24\%) compared with the middle-social-group girls $(15 \%)$.

Alongside the fall in reported EI over the past two decades, an increase in the incidence of overweight and obesity of children has occurred. This trend has been apparent in the UK and also in American adolescents (Department of Health, 1989a; Reilly et al. 1999; Gregory et al. 2000; Chinn \& Rona, 2001; Ogden et al. 2002). In the 2000 study almost one in three children in the present study were classified as overweight or obese when using the international adolescent BMI cut-offs (Cole et al. 2000). In 2000 , the BMI of boys $\left(19.7 \mathrm{~kg} / \mathrm{m}^{2}\right)$ and girls $(20.0 \mathrm{~kg} /$ $\mathrm{m}^{2}$ ) were similar to UK boys and girls aged $11-14$ years old in 1997 (Gregory et al. 2000). One explanation for the falling EI, yet rise in BMI, could be a decline in physical activity levels, an increase in the level of under-reporting or, as is most likely to be the case, a combination of these two factors. Gregory et al. (2000) found about $40 \%$ of boys and $60 \%$ of girls did not meet the Health Education Authority requirements of at least $1 \mathrm{~h} / \mathrm{d}$ in activity of at least moderate intensity (Biddle et al. 1998). The increase in overweight and obesity reported in the present study and elsewhere is alarming. Adolescent obesity has detrimental effects in adolescence as well as being predictive of adult obesity (Power et al. 1997; Mascarenhas et al. 1999). Type 2 diabetes has been found in the UK among overweight and obese children of South Asian origin and more recently amongst white teenagers (Ehtisham et al. 2000; Drake et al. 2002).

UK recommendations for percentage energy from fat are set at $<35 \%$ (Department of Health, 1991). Between 1980 and 1990 the percentage energy from fat remained high at $40 \%$ and similar to that reported for the national survey of British schoolchildren in 1983 (Department of Health, 1989a). Between 1990 and 2000, considerable decreases in fat intake, equivalent to $5 \%$ of $\mathrm{EI}$, were observed in both the present study and the 1997 national survey (Gregory et al. 2000). Dietary intakes of Swiss 11- to 16-year-olds, obtained by $3 \mathrm{~d}$ weighed intakes, found percentage energy from fat intakes to be $37 \%$ (Decarli et al. 2000). Percentage energy from fat by American adolescents was reported to have fallen but was still above the US recommendation (currently 30\%; Nicklas 1995; Cavadini et al. 2000). In our 1980 survey, $7 \%$ of boys and $3 \%$ of girls in the low social group were achieving the national recommendation of less than $35 \%$ energy from fat, while by $2000,40 \%$ of children in the low social group were meeting this recommendation. Children from the higher social group were more likely to meet this recommendation ( $61 \%$ of boys and $50 \%$ of girls). In contrast, no differences were found in percentage energy from fat intakes by socio-economic status in the NDNS report of 4- to 18-year-olds.

The percentage energy consumed as carbohydrate remained virtually unchanged from 1980 to 1990 at 49 and $48 \%$, respectively, but increased to $53 \%$ in 2000 . The recommended intake is at least $50 \%$ energy from carbohydrate (Department of Health, 1991) and the national surveys showed only a modest increase of $1 \%$ from $1983(51 \%)$ to 1997 (52\%) (Department of Health, 1989a; Gregory et al. 2000). Percentage energy from 
starch remained constant between 1980 and 1990, but increased by $3 \%$ in 2000 to $30 \%$; intakes were similar between sexes and social classes. This positive increase occurred despite percentage energy from NMES remaining high at $16 \%$ (recommendation set at $10 \%$; Department of Health, 1991). Absolute NMES intakes increased between $1980(80 \mathrm{~g})$ and $1990(90 \mathrm{~g})$ but fell slightly in $2000(82 \mathrm{~g})$; boys were more likely to consume higher intakes of NMES than the girls, yet percentage energy from NMES was similar $(16 \%)$. NMES remain the major dietary cause of dental caries (Rugg-Gunn \& Nunn, 2000) and a reduction in NMES is necessary for further reduction in this prevalent disease.

Unavailable carbohydrate intakes increased by $2 \mathrm{~g} / \mathrm{d}$ between 1980 and 1990, and continued to increase in boys in 2000. Unavailable carbohydrate (Wenlock et al. 1985) was the only method for determining dietary fibre in 1980. The NSP (Englyst et al. 1989) method is now used but such data from the present study are available for 1990 and 2000 only. NSP intakes increased between 1990 and 2000 for boys and girls, with boys consuming significantly higher NSP intakes than girls. There are no NSP recommendations for children, but adult requirements are 18 (range 12-24) g/d (Department of Health, 1991). NSP intakes for boys and girls were lower than adult recommendations, at 11.1 and $10.2 \mathrm{~g}$, respectively and were similar to the NDNS findings of 11.6 and $10.2 \mathrm{~g}$ for boys and girls, respectively (Gregory et al. 2000). The adult recommendations can be extrapolated based on EAR for energy to give recommendations of $16 \mathrm{~g} / \mathrm{d}$ for boys and $17 \mathrm{~g} / \mathrm{d}$ for girls; mean intakes from the present study were below these values.

The UK government's 'Our Healthier Nation' (Department of Health, 1999) emphasised the importance of reducing health inequalities between the low and high social classes. These surveys have shown some improvements in diet for boys and girls and all social groups between 1980 and 2000 when compared with national recommendations. In 2000, children of lower social class were more likely to meet requirements for energy, while, for percentage energy from fat, children in the higher social group were more likely to achieve the target of less than $35 \%$. For protein, few boys from any social group had intakes below the reference nutrient intake, while for girls a social-group trend was apparent; $24 \%$ of girls in the lower social group had intakes below the reference nutrient intake compared with $17 \%$ of the high-socialgroup girls. Social-group trends have been found in many studies (Cook et al. 1973; Durnin et al. 1974; Department of Health, 1989a; Ruxton et al. 1996; Gregory et al. 2000). Although the gap between the quality of diet of the high and low social groups is well recognised by health educators, the present study highlights that this is still an area of concern.

\section{Conclusions}

Our findings indicate some welcome changes and other areas of concern for those involved in conveying public health messages. The health message of reducing fat (as a proportion of energy) may have had a positive effect amongst adolescents in the north east of England over the past 10 years. This change has been accompanied by an increase in percentage energy from starch yet sugar intakes as a proportion of energy have remained above recommendations. It is important to build on the increase in starch intakes with the aim of increasing the proportion of children who meet the recommendation for fat intake and reducing NMES intakes. Reported EI have fallen between 1980 and 2000 which, if a true reflection of habitual intake, makes the quality of the diet increasingly important. It must be noted however that an analysis of 'valid reporters' casts some doubt on the extent of this fall, which warrants further investigation. Reduced reported EI have occurred alongside a substantial increase in the number of overweight and obese children. The serious health implications associated with adolescent obesity make prevention and treatment of obesity a priority. Public health messages emphasising the need to increase physical activity and replace high-fat and sugar-rich foods with nutrient-dense foods need to be conveyed to children and adolescents. Adolescence is a time of increased freedom of food choice and is a crucial time to influence both adolescents and their parents to increase consumption of alternative foods low in fat and sugar but high in starch and nutrient density.

\section{Acknowledgements}

The authors are most grateful to the Northumberland Health and Education Authorities, and to the school staff and pupils involved. Ms Tessa Staples of the Occupational Information Unit of the Office of National Statistics very kindly coded the parental occupations. Finally, we are grateful to the Northern Regional Health Authority and Newcastle University Dental School Bradlaw Fund for financing the study.

\section{References}

Adamson A, Rugg-Gunn A, Butler T, Appleton D \& Hackett A (1992) Nutritional intake, height and weight of 11-12-yearold Northumbrian children in 1990 compared with information obtained in 1980. Br J Nutr 68, 543-563.

Adamson AJ, Rugg-Gunn AJ, Butler TJ \& Appleton DR (1996) The contribution of foods from outside the home to the nutrient intake of young adolescents. J Hum Nutr Diet 9, 55-68.

Anonymous (1983) Obesity. A report of the Royal College of Physicians. J R Coll Physicians Lond 17, 3-65.

Bandini LG, Schoeller DA, Cyr HN \& Dietz WH (1990) Validity of reported energy intake in obese and non-obese adolescents. Am J Clin Nutr 52, 421-425.

Bellizzi MC \& Dietz WH (1999) Workshop on childhood obesity: summary of the discussion. Am J Clin Nutr 70, 173S-175S.

Biddle S, Sallis J \& Cavill N (editors) (1998) Young and Active? Young People and Health Enhancing Physical Activity Evidence and Implication. London: Health Education Authority.

Cavadini C, Siega-Riz AM \& Popkin BM (2000) US adolescent food intake trends from 1965 to 1996. Arch Dis Child 83, $18-24$.

Chan W, Brown J \& Buss DH (1994) Miscellaneous Foods: Supplement to McCance and Widdowson's The Composition of 
Foods. London: Royal Society of Chemistry and Ministry of Agriculture, Fisheries and Food.

Chan W, Brown J, Church SM \& Buss DH (1996) Meat Products and Dishes. Sixth Supplement to McCance and Widdowson's The Composition of Foods, 5th ed. London: Royal Society of Chemistry and Ministry of Agriculture, Fisheries and Food.

Chan W, Brown J, Lee S \& Buss DH (1995) Meat, Poultry and Game. Fifth Supplement to McCance and Widdowson's The Composition of Foods, 5th ed. London: Royal Society of Chemistry and Ministry of Agriculture, Fisheries and Food.

Chinn S \& Rona RJ (2001) Prevalence and trends in overweight and obesity in three cross sectional studies of British children, 1974-94. BMJ 322, 24-26.

Cole TJ, Bellizzi MC, Flegal KM \& Dietz WH (2000) Establishing a standard definition for child overweight and obesity worldwide: international survey. BMJ 320, 1240-1243.

Cole TJ, Freeman JV \& Preece MA (1995) Body mass index reference curves for the UK, 1990. Arch Dis Child 73, 25-29.

Cook J, Altman DG, Moore DMC, Topp SG, Holland WW \& Elliot A (1973) A survey of the nutritional status of schoolchildren relation between nutrient intake and socio-economic factors. Br J Prev Soc Med 27, 91-99.

Darke SJ, Disselduff MM \& Try GP (1980) A nutrition survey of children from one-parent families in Newcastle upon Tyne in 1970. Br J Nutr 44, 237-241.

Decarli B, Cavadini C, Grin J, Blondel-Lubrano A, Narring F \& Michaud PA (2000) Food and nutrient intakes in a group of 11 to 16 year old Swiss teenagers. Int J Vitam Nutr Res 70, $139-147$.

Department of Health (1989a) The Diets of British School Children. Report on Health and Social Subjects no. 36. London: HM Stationery Office.

Department of Health (1989b) Dietary Sugars and Human Disease. Report on Health and Social Subjects no. 37, London: HM Stationery Office.

Department of Health (1991) Dietary Reference Values for Food Energy and Nutrients for the United Kingdom. Report on Health and Social Subjects no. 41. London: HM Stationery Office.

Department of Health (1992) The Health of the Nation: a Strategy for Health in England. London: The Stationery Office.

Department of Health (1994) Nutritional Aspects of Cardiovascular Disease. Report on Health and Social Subjects no. 46. London: HM Stationery Office.

Department of Health (1999) Saving Lives: Our Healthier Nation. London: The Stationery Office.

Department of Health and Social Security (1984) Diet and Cardiovascular Disease. Report on Health and Social Subjects no. 28. London: HM Stationery Office.

Dietz WH \& Bellizzi MC (1999) Introduction: the use of body mass index to assess obesity in children. Am J Clin Nutr 70, $123 \mathrm{~S}-125 \mathrm{~S}$.

Drake AJ, Smith A, Betts PR, Crowne EC \& Shield JPH (2002) Type 2 diabetes in obese white children. Arch Dis Child 86, 207-208.

Durnin JVGA, Lonergan ME, Good J \& Ewan A (1974) A crosssectional nutritional and anthropometric study, with an interval of seven years on 611 young adolescent schoolchildren. $\mathrm{Br} \mathrm{J}$ Nutr 32, 169-179.

Ehtisham S, Barrett TG \& Shaw NJ (2000) Type 2 diabetes mellitus in UK children - an emerging problem. Diabet Med 17, 867-871.

Englyst HN, Bingham S, Collinson E, Ruswick S \& Cummings JH (1989) Dietary fibre (non-starch polysaccharides) in cereal products. J Hum Nutr Diet 2, 253-271.

Freeman JV, Cole TJ, Chinn S, Jones PRM, White EM \& Preece
MA (1995) Cross sectional stature and weight reference curves for the UK, 1990. Arch Dis Child 73, 17-24.

Goldberg GR, Black AE, Jebb SA, Cole TJ, Murgatroyd PR, Coward WA \& Prentice AM (1991) Critical evaluation of energy intake data using fundamental principles of energy physiology 1: Derivation of cut-off values to identify under recording. Eur J Clin Nutr 45, 569-581.

Gregory J, Lowe S, Bates CJ, Prentice A, Jackson LV, Smithers G, Wenlock R \& Farron M (2000) National Diet and Nutrition Survey: Young People aged 4 to 18 Years, vol. 1, London: The Stationery Office.

Guo SS \& Chumlea WC (1999) Tracking of body mass index in children in relation to overweight in adulthood. Am J Clin Nutr 70, $145 \mathrm{~S}-148 \mathrm{~S}$.

Hackett AF, Kirby S \& Howie M (1997) A national survey of the diet of children aged 13-14 years in urban areas of the United Kingdom. J Hum Nutr Diet 10, 37-51.

Hackett AF, Rugg-Gunn AJ \& Appleton DR (1983) Use of a dietary diary and interview to estimate the food intake of children. Hum Nutr Appl Nutr 37A 293-300.

Hackett AF, Rugg-Gunn AJ, Appleton DR, Eastoe JE \& Jenkins GN (1984a) A 2-year longitudinal nutritional survey of 405 Northumberland children initially aged 11.5 years. Br J Nutr 51, 67-75.

Hackett AF, Rugg-Gunn AJ, Appleton DR, Parkin JM \& Eastoe JE (1984b) A two-year longitudinal study of dietary intake in relation to the growth of 405 English initially aged 11-12 years. Ann Hum Biol 11, 545-553.

Holland B, Brown J \& Buss DH (1993) Fish and Fish Products: The Third Supplement to McCance and Widdowson's The Composition of Foods, 5th ed. London: Royal Society of Chemistry and Ministry of Agriculture, Fisheries and Food.

Holland B, Unwin ID \& Buss DH (1988) Cereals and Cereal Products: The Third Supplement to McCance and Widdowson's The Composition of Foods, 4th ed. London: Royal Society of Chemistry and Ministry of Agriculture, Fisheries and Food.

Holland B, Unwin ID \& Buss DH (1989) Milk Products and Eggs: The Fourth Supplement to McCance and Widdowson's The Composition of Foods, 4th ed. London: Royal Society of Chemistry and Ministry of Agriculture, Fisheries and Food.

Holland B, Unwin ID \& Buss DH (1991) Vegetables, Herbs and Spices: The Fifth Supplement to McCance and Widdowson's The Composition of Foods, 4th ed. London: Royal Society of Chemistry and Ministry of Agriculture, Fisheries and Food.

Holland B, Unwin ID \& Buss DH (1992a) Fruit and Nuts: The First Supplement to McCance and Widdowson's The Composition of Foods, 5th ed. London: Royal Society of Chemistry and Ministry of Agriculture, Fisheries and Food.

Holland B, Welch AA \& Buss DH (1992b) Vegetable Dishes: The Second Supplement to McCance and Widdowson's The Composition of Foods 5th ed. London: Royal Society of Chemistry and Ministry of Agriculture, Fisheries and Food.

Macdiarmid JI \& Blundell JE (1997) Dietary underreporting: what people say about recording their food intake. Eur J Clin Nutr 51, 199-200.

McNeill G, Davidson L, Morrison DC, Crombie IK, Keighran J \& Todman J (1991) Nutrient intake in schoolchildren: some practical considerations. Proc Nutr Soc 50, 37-43.

Malina RM \& Katzmarzyk PT (1999) Validity of the BMI as an indicator of the risk and presence of overweight in adolescents. Am J Clin Nutr 70, 131S-136S.

Mascarenhas MR, Tershakovec AM \& Stettler N (1999) Nutrition interventions in childhood for the prevention of chronic diseases in adulthood. Curr Opin Pediatr 11, 598-604.

National Advisory Committee on Nutrition Education (1983) A Discussion Paper on Proposals for Nutritional Guidelines for 
Health Education in Britain. London: Health Education Council.

National Audit Office (2001) Tackling Obesity in England. Report by the Controller and Auditor General no. HC220. London: The Stationery Office.

Nelson M \& Naismith D (1979) The nutritional status of poor children in London. J Hum Nutr 33, 33-45.

Nelson M, Naismith DJ, Burley V, Gatenby S \& Geddes N (1990) Nutrient intakes, vitamin-mineral supplementation, and intelligence in British schoolchildren. Br J Nutr 64, 13-22.

Nicklas TA (1995) Dietary studies of children: the Bogalusa heart study experience. J Am Diet Assoc 95, 1127-1133.

Office of National Statistics (2000) Standard Occupational Classification 2000, vol. 2. The Coding Index. London: The Stationery Office.

Office of Population Censuses and Surveys (1990) Standard Occupational Classification, vol. 3. London: HM Stationery Office.

Office of Population Censuses and Surveys (1993) Census County Report: Northumberland (Part 2). London: HM Stationery Office.

Ogden CL, Flegal KM, Carroll MD \& Johnson CL (2002) Prevalence and trends in overweight among US children and adolescents, 1999-2000. JAMA 288, 1728-1732.

Power C, Lake JK \& Cole TJ (1997) Measurement and long-term health risks of child and adolescent fatness. Int J Obes Relat Metab Disord 21, 507-526.

Prentice AM \& Jebb SA (1995) Obesity in Britain: gluttony or sloth? BMJ 311, 437-438.

Prentice AM \& Jebb SA (2001) Beyond body mass index. Obes Rev 2, 141-147.

Registrar General (1980) Classification of Occupations 1980. Office of Population Censuses and Surveys. London: HM Stationery Office.

Reilly JJ, Dorosty AR \& Emmett PM (1999) Prevalence of overweight and obesity in British children: cohort study. BMJ 319, 1039.
Rugg-Gunn AJ, Hackett AF, Appleton DR \& Moynihan PJ (1986) The dietary intake of added and natural sugars in 405 English adolescents. Hum Nutr Appl Nutr 40A 115-124.

Rugg-Gunn AJ \& Nunn JH (2000) Nutrition, Diet and Oral Health. Oxford: Oxford University Press.

Ruxton CHS, Kirk TR, Belton NR \& Holmes NA (1996) Relationship between social class, nutrient intake and dietary patterns in Edinburgh schoolchildren. Int J Food Sci Nutr 47, 341-349.

Sanchez-Castillo CP, Franklin M, McNeill G, de Lourdes Solano M, Bonner S, Lopez N, Davidson L \& James WP (2001) Are the proposed limits of energy intake:basal metabolic rate and dietary nitrogen:urinary nitrogen ratios suitable for validation of food intake? Br J Nutr 85, 725-731.

Schoeller DA (1990) How accurate is self-reported dietary energy intake? Nutr Rev 48, 373-379.

Schofield WN (1985) Predicting basal metabolic rate, new standards and review of previous work. Hum Nutr Clin Nutr 39C $5-41$.

StataCorp (2001) Stat Statistical Software: Release 7.0. College Station, TX: Stata Corporation.

Strain JJ, Robson PJ, Livingstone MBE, Primrose ED, Savage JM, Cran GW \& Boreham CA (1994) Estimates of food and macronutrient intake in a random sample of Northern Ireland adolescents. Br J Nutr 72, 343-352.

Tan SP, Wenlock RW \& Buss DH (1985) Immigrant Foods. Second Supplement to McCance and Widdowson's The Composition of Foods. London: Royal Society of Chemistry and Ministry of Agriculture, Fisheries and Food.

Townsend P, Phillimore P \& Beattie A (1988) Health and Deprivation: Inequality in the North. London: Croom Helm.

Wenlock RW, Sivell LM \& Agater IB (1985) Dietary fibre fractions in cereal and cereal-containing products in Britain. $J$ Sci Food Agric 36, 113-121.

Whitehead RG, Paul AA \& Cole TJ (1982) Trends in food energy intakes throughout childhood from 1-18 years. Hum Nutr Appl Nutr 36, 57-62. 